\section{Thoughts on patriarchy}

I felt I could not let the diatribe ${ }^{1}$ posing as a scientific article by Professor Malcolm Potts and his wife, Dr Martha Campbell, go without comment. When one reads an article that contains gross inaccuracy, even in part, the credibility of the rest and of the journal running it is thrown into question.

The couple has an understandable modern problem with St Augustine but that is no excuse for their absurdly inaccurate summary of over a hundred theological works, ${ }^{2}$ that he "saw God as an arbitrary judge who could be placated by bribes". Nor does it justify ridiculing him from a 21 st century perspective with no attempt to understand his historical or personal context, or indeed any of their other (highly selected) examples. To then link patron saints in a non sequitur to bribery and the etymology of 'grace' (wrongly) $)^{3}$ to the same is as ridiculous as it is irrelevant. (I note they are only able to quote Potts' own authority for this.)

To limit the development of Christian sexual ethics only to the context of sexual exploitation tolerated in the Roman Empire is profoundly misleading. They show no awareness of the contributing influences of Judaism, Hellenism, Stoicism or Gnosticism 4

Just how blinkered the authors' historical viewpoint is can be seen from the fact that the discussion is limited to one theologian among many, to only the Western tradition, ignoring Eastern and Celtic perspectives completely, and subsequently narrowing within that to Roman Catholicism.

Islam fares worse, seeming only to be represented by the Taliban in the authors' minds. If the two faiths both have "liberal and conservative interpretations", why is discussion limited to the negative ones?

The most one can learn from this article is something of the prejudices of its authors. This is not the first time Malcolm Potts has been accused of a lack of objectivity. 5

Space precludes a more detailed response but I wonder how this got through the Journal's peer review process. It would have been sensible to mention Martha Campbell's membership of the Editorial Advisory Board as a competing interest. In a journal aspiring to international scientific respectability, authors should be obliged to give balanced and informed discussion. If polemic is to be part of the offering, it should be flagged as such.

I am certainly no friend of patriarchy, but a scientific article is not the place to abandon balance in favour of rhetoric.

David Shepherd, BMBCh, MRCGP

General Practitioner, Saffron Group Practice,

Leicester,UK.E-mail: daveshep@nhs.net

Competing interest The author is in training as a Reader in the Church of
England.

\section{References}

Potts M, Campbell M. The origins and future of patriarchy: the biological background of gender politics. J Fam Plann Reprod Health Care 2008; 34:

2 Augustine of Hippo. http://en.wikipedia.org/wiki/ Augustine_of_Hippo\#cite_note-12 [Accessed 28 June 2008.

3 Grace. http://en.wiktionary.org/wiki/grace\#Etymology [Accessed 28 June 2008].

Farley M. Sexual ethics. In: Nelson JB, Longfellow S eds), Sexuality and the Sacred. Louisville, KY

5 Smith V. Rose-tinted spectacles. Rapid Responses to: Malcolm Potts. China's one child policy. BMJ 2006; 7564/361 [Accessed 28 June 2008].

\section{Reply}

We appreciate Dr Shepherd's broader view of other strains of Catholicism. ${ }^{1}$ However, our article was not a book, but a glance at those streams of patriarch that are doing most damage to women's health. We did not try to be comprehensive and our discussion focuses not on the liberal wings of Christianity and Islam but rather on the conservative, because these represent seven-eighths of their history, and the shadow of conservatism seems to last longest in the area of human sexuality.

Dr Shepherd is also correct that striving to understand the historical context in which key actors such as Augustine of Hippo lived is centra to historical scholarship. But it is precisely that historical context which we find so brutally patriarchal. We took part of our analysis from careful historians of Christianity, such as Susan Haskins, ${ }^{2}$ Marina Warner, ${ }^{3}$ Elaine Pagels ${ }^{4}$ and Uta Ranke-Heinemann ${ }^{5}$ In addition, some of the insights into Augustine came from a patristic historian and theologian, the late Francis Xavier Murphy, who taught moral theology at the Academia Alfonsiana in Rome and who was a peritus (expert adviser) to the Second Vatican Council. ${ }^{6} \mathrm{He}$ was a personal friend and mentor of one of us (MP)

\section{Malcolm Potts, PhD, FRCOG}

Bixby Professor, School of Public Health,

University of California, Berkeley, CA, USA.

E-mail:potts@berkeley.edu

\section{Martha M Campbell, $\mathrm{PhD}$}

President and CEO, Venture Strategies Innovations, Berkeley, CA and Lecturer, School of Public Health, University of

California, Berkeley, CA, USA.

E-mail: campbell@berkeley.edu

\section{References \\ Shepherd D. Thoughts on patriarchy [Letter]. J Fam Plann Reprod Health Care 2008; 34: 272 . \\ Haskins S. Mary Magdalen. London, UK: Harper Collins, 1993. \\ Warner M. Alone of All Her Sex: The Myth and the Cult of the Virgin Mary. New York, NY: Alfred A Knopf, 1976. Pagels E. Adam, Eve, and the Serpent. New York, NY: Random House, 1988. \\ 5 Ranke-Heinmann U. Eunuchen fur das Himmelreich (translated by John Brownjohn as Eunuchs for Heaven.). London, UK: Andre Deutsch, 1999. \\ 6 Rynne X (aka Murphy FX). Vatican Council II. New York, NY: Orbis Books, 1999 .}

\section{Implant removal by modifying}

I read with great interest the review articles by Diana Mansour and colleagues on 'Methods of accurate localisation of the non-palpable subdermal contraceptive implant' and 'Removal of non-palpable etonogestrel implants' in the January and April 2008 issues of the Journal, respectively. 1,2 I totally agree with the author's suggestion to modify access with $2-3 \mathrm{ml}$ of local anaesthetic applied under the palpable portion. This helped me greatly to modify the procedure, depending upon the patient's clinical circumstances and requirements as outlined in the following two cases.

Case 1: A 24-year-old mother of two children was fitted with Implanon ${ }^{\circledR} 18$ months previously. The patient requested removal of the Implanon for her next conception. On examination the distal end of the implant was non-palpable and the proximal end was palpable with difficulty. An ultrasound scan was done as suggested in the article. The ultrasound report noted that: "the Implanon is located in the left arm, the lower edge is marked and is at a depth of $1.6 \mathrm{~cm}$. The upper edge is palpable". After explaining the possible difficulties, I obtained fully informed, written consent from the patient for removal of her implant. I made a $4 \mathrm{~mm}$ incision at the proximal, barely palpable, end of the Implanon and dissected with small curved mosquito forceps and finally managed to get the Implanon ou without any surgical complications. Here realised the importance of having an assistant and the use of small skin retractors, which were mentioned in the article but which were not available in our clinic. Consequently we ordered two small skin retractors with immediate effect for future use.

Case 2: A 38-year-old Zimbabwean woman was referred to me by a colleague for removal of a Norplant ${ }^{\circledR}$ device inserted 6 years ago in Zimbabwe. I explained to the patient that I am not trained in Norplant insertion or removal, although I am trained and experienced in Implanon insertion and removal. Consequently I suggested referral to a doctor trained in Norplant insertion/removal. The patient declined referral and insisted that I undertake the removal procedure. On examination, four of the rods were palpable and close together and a few millimetres above the insertion scar. Although the rods on either side were about $1.5 \mathrm{~cm}$ away, they were superficial and easily palpable. I explained to the patient that the middle four rods could be removed by means of the 'pop-out' technique with one incision and the remaining two rods could be removed by the same technique but with two separate incisions, similar to Implanon removal. The patient happily gave written consent to this suggested treatment plan and accepted the risks and complications (if any) of the procedure such as multiple scars, infection, bruises, nerve and vessel injury and their consequences.

Even though the Mansour et al. article mentioned a vertical incision for removal I went through the original horizontal scar and carefully dissected tissues vertically and removed four rods by directing each of them to the incision. Rather than attempting the heroic removal of the remaining two rods (located laterally and above) through the same incision, I felt it was much safer and easier to employ two small incisions $(<2 \mathrm{~mm}$ each) and use the 'pop-out' technique, similar to Implanon removal. This avoided a T-incision with the old scar and I hope the patient will end up with only the single, old incision scar. A patient review visit after 1 week confirmed a nicely healing wound. I discharged the patient from the clinic since she had not decided on her future contraception, except the use of condoms. The patient was extremely happy to have avoided referral to an unknown clinic for removal of her Norplant

C Chandy, FRCOG, MFSRH

Associate Specialist in Sexual Health, Tameside and Glossop Primary Care Trust, Crickets Lane Clinic, Ashton-under-Lyne,UK. E-mail: cchandy@nhs.net

References

Mansour D, Fraser IS, Walling M, Glenn D, Graesslin $\mathrm{O}$, Egarter $\mathrm{C}$, et al. Methods of accurate localisation of non-palpable subdermal contraceptive implants. J Fam Plann Reprod Health Care 2008; 34: 9-12

2 Mansour D, Walling M, Glenn D, Egarter C, Graesslin $\mathrm{O}$, Herbst $\mathrm{J}$, et al. Removal of non-palpable etonogestrel implants. J Fam Plann Reprod Health Care 2008; 34: 89-91.

\section{Norplant removal forceps}

I was interested to read the article by Diana Mansour et al. ${ }^{1}$ reviewing removal techniques for contraceptive implants.

In common, I am sure, with many other readers, I am continuing to see patients requiring Norplant ${ }^{\circledR}$ removal who have had this implant fitted outside the UK.

Our primary care trust has opted for a singleuse instruments policy, and we have had to get rid of our desktop sterilisers, so we are no longer able to reuse the modified vasectomy forceps ("Norplant removers") with a $2.2 \mathrm{~mm}$ diameter, referred to in the article.

The best that any of the single-use manufacturers I have contacted can come up with is disposable vasectomy forceps with an internal diameter of approximately $4 \mathrm{~mm}$, which allow the Norplant rods to slip during "U" removals (Figure 1, right)

I am left with the unsatisfactory situation of using the wrong instruments, or referring to the 